\title{
Hypermethylated promoters of tumor suppressor genes were identified in Crohn's disease patients
}

\author{
Tae-Oh Kim ${ }^{1}$, Yu Kyeong Han ${ }^{2}$, Joo Mi Yi ${ }^{2}$ \\ ${ }^{I}$ Department of Internal Medicine, Inje University Haeundae Paik Hospital, Busan; ${ }^{2}$ Department of Microbiology and Immunology, Inje \\ University College of Medicine, Busan, Korea
}

Background/Aims: Overwhelming evidence suggests that inflammatory bowel disease (IBD) is caused by a complicated interplay between the multiple genes and abnormal epigenetic regulation in response to environmental factors. It is becoming apparent that epigenetic factors are significantly associated with the development of the disease. DNA methylation remains the most studied epigenetic modification, and hypermethylation of gene promoters is associated with gene silencing. Methods: DNA methylation alterations may contribute to the many complex diseases development by regulating the interplay between external and internal environmental factors and gene transcriptional expression. In this study, we used 15 tumor suppressor genes (TSGs), originally identified in colon cancer, to detect promoter methylation in patients with Crohn's disease (CD). Methylation specific polymerase chain reaction and bisulfite sequencing analyses were performed to assess methylation level of TSGs in CD patients. Results: We found 6 TSGs (sFRP1, sFRP2, sFRP5, TFPI2, Sox17, and GATA4) are robustly hypermethylated in CD patient samples. Bisulfite sequencing analysis confirmed the methylation levels of the $s F R P 1, s F R P 2$, sFRP5, TFPI2, Sox17, and GATA4 promoters in the representative CD patient samples. Conclusions: In this study, the promoter hypermethylation of the TSGs observed indicates that CD exhibits specific DNA methylation signatures with potential clinical applications for the noninvasive diagnosis of IBD and the prognosis for patients with IBD. (Intest Res 2020;18:297-305)

Key Words: DNA methylation; Promoter; Crohn disease; Genes, Tumor suppressor

\section{INTRODUCTION}

Inflammatory bowel disease (IBD) comprising CD and UC is believed to reflect complex interplay between genetic and environmental factors. CD is one of the major type of IBD. CD and UC exhibit etiologically distinct characters. CD often involves in the ileum and colon mostly but also can involves in any region of the gut. UC mostly common involves the rectum, and it has been known that the inflammation may extend the cecum in a contiguous pattern. ${ }^{1}$ Inflammatory diseases such as CD are usually affected due to genetic factors

Received August 23, 2019. Revised November 18, 2019.

Accepted November 18, 2019.

Correspondence to Joo Mi Yi, Department of Microbiology and Immunology,

Inje University College of Medicine, 75 Bokji-ro, Busanjin-gu, Busan 47392,

Korea. Tel: +82-51-890-6451, Fax: +82-51-891-6004, E-mail: jmyi76@inje.

ac.kr and environmental factors. ${ }^{2}$ A recent genome-wide association study successfully identified more than 200 CD-associated loci at the level of genome-wide significance. ${ }^{3,4}$ However, these findings could only address a few part of the IBD pathogenesis. Numerous genetic, clinical, and multiple experimental studies should have been proved to our understanding of the etiology of IBD.

DNA methylation, predominantly occurring in the $\mathrm{CpG}$ dinucleotide of the genome, is a key epigenetic mechanism that can regulate gene expression and therefore can affect to the development and progression of complex diseases including cancer. ${ }^{5}$ Aberrant DNA methylation frequently involves in inactivation of tumor suppressor genes (TSGs) in human cancers. ${ }^{5}$ Among others, the transcriptional silencing of tumor suppressor candidate genes is regulated by promoter hypermethylation in colorectal cancer (CRC) by our group and oth- 
er groups as well. ${ }^{6,7}$ High-throughput genome-wide methylation studies provide a brand-new approach to understand the importance of DNA methylation at the whole genome level and its impact on gene regulation. ${ }^{6,8}$ Therefore, the role of DNA methylation has been widely studied in many different cancer types and other human diseases, such as IBD. ${ }^{9}$ For example, abnormal DNA methylation of the estrogen receptor, $p 14^{\mathrm{ARF}}$, and E-cadherin genes has been detected in UC patients. In addition, there is growing evidence that epigenetic changes in the regulation of gene expression are critical factors in the pathogenesis of IBD. ${ }^{10,11}$ Many studies have used these wellknown TSG candidates to investigate other cancers, such as lung, breast, and pancreatic cancer. ${ }^{7,12}$ We previously have reported that $\mathrm{CpG}$ islands in the promoter region of TCERG1L is abnormally hypermethylated at high frequency not only in colon cancer patient tissues, ${ }^{13}$ but also in patients with UC. ${ }^{14}$ However, few studies have been conducted on the DNA methylation profiles of these TSGs in patient with CD.

We tested the promoter hypermethylation of 18 tumor suppressor candidates (TFPI2, GATA4, p16, sFRP1, sFRP4, MGMT, Sox17, HIC1, sFRP2, sFRP5, p14, p15, GATA5, E-cadherin, and Timp3) in a limited number of tissue samples from Korean patients with $C D(n=15)$. Interestingly, we detected the abnormal promoter hypermethylation of several TSGs in patients with CD: SFRP1, SFRP2, SFRP5, TFPI2, Sox17, and GATA4 were aberrantly hypermethylated with high frequency in most of the CD patient tissues. Our data suggest that the methylation status of 6 genes in patients with CD has the potential to become a marker of risk for the progression of severe disease.

\section{METHODS}

\section{Patients and Samples}

The CD and normal colon biospecimens for this study were provided by the Inje Biobank (Inje University School of Medicine), a member of the National Biobank of Korea, which is supported by the Ministry of Health and Welfare. Tissue samples were collected from the ascending colon at the time of colonoscopy. Of the 15 subjects, 10 were male and 5 female, yielding a male to female ratio of 2:1. The median age at diagnosis of CD was 28.4 years (range, 18-45 years). CD was diagnosed on the basis of conventional clinical, radiologic, endoscopic, and histopathologic criteria. At the time of diagnosis, 3 patients (20\%) had disease in the colon alone (L2), and 12 $(80 \%)$ had disease in the small bowel and colon (L3). Disease behavior at diagnosis was inflammatory (B1) in 10 patients
Table 1. Characteristics of Samples of Patient with CD

\begin{tabular}{lc}
\hline Characteristic & Value $(\mathrm{n}=15)$ \\
\hline Age (yr) & $28.4(18.0-45.0)$ \\
Sex & $10(66.7)$ \\
Male & $5(23.3)$ \\
Female & \\
Disease location at diagnosis & 0 \\
Small bowel alone (L1) & $3(20.0)$ \\
Colon alone (L2) & $12(80.0)$ \\
Small bowel and colon (L3) & \\
Disease behavior at diagnosis & $10(66.7)$ \\
Inflammatory (B1) & $4(26.7)$ \\
Stricturing (B2) & $1(6.6)$ \\
Penetrating (B3) &
\end{tabular}

Values are presented as median (range) or number (\%).

(66.7\%), stricturing (B2) in 4 (26.7\%), and penetrating (B3) in $1(6.6 \%)$. Clinical characteristics of these patients are shown in Table 1. This study was approved by the respective institutional review board (IRB No. 129792-2015-056) of the participating institutions of the National Biobank of Korea, and written informed consent was obtained for all study participants prior to data collection.

\section{Genomic DNA Extraction and DNA Methylation Analyses}

Genomic DNA was extracted following a standard phenolchloroform extraction protocol. Bisulfite modification of DNA was performed using the EZ DNA Methylation Kit (Zymo Research, Irvine, CA, USA) according to the manufacturer's instructions. Methylation analysis by methylation-specific PCR (MSP) was carried out in a $25-\mu \mathrm{L}$ reaction of $10 \times$ PCR buffer, $10 \mathrm{mM}$ dNTPs (deoxyribonucleotide triphosphates), $10 \mathrm{pmol}$ of each of the methylated or unmethylated primers, 1 unit of JumpStart ${ }^{\mathrm{TM}}$ REDTaq $^{\circledR}$ DNA polymerase (Sigma, St. Louis, MO, USA) and $4 \mu \mathrm{L}$ of bisulfite-treated DNA. The detailed information of primer was listed in in Table 2. Cycling condition were: 5 minutes at $95^{\circ} \mathrm{C}$ followed by 35 repeats of the following cycle: $95^{\circ} \mathrm{C}$ for 30 seconds, annealing at the appropriate temperature for 30 seconds. In vitro methylated DNA was used as a positive control.

\section{Bisulfite Sequencing Analysis}

Bisulfite modification of DNA was used for PCR reaction to clone alleles of target amplicons. The PCR amplicons were gel- 
Table 2. MSP Primers Information in This Study

\begin{tabular}{|c|c|c|c|}
\hline \multirow{2}{*}{ Gene } & \multirow{2}{*}{ Target } & \multicolumn{2}{|c|}{ Methylation-specific PCR } \\
\hline & & Forward primer (5'-3') & Reverse primer (5'-3') \\
\hline \multirow[t]{2}{*}{ TFPI2 } & Unmethylation & CCCACATAAAACAAACACCCAAACCA & TGGTTGTGGGTAAGGTGTTG \\
\hline & BS-Seq & GGTIATGGTGTAGGGG & САATCACTAАСАAАТСАПТСС \\
\hline \multirow[t]{2}{*}{ GATA4 } & Unmethylation & ПாGTATAGTITGTAGחTGTGחTAGT & СССААСТСАСААСТСАААТССССА \\
\hline & BS-Seq & СТССААСССУАССТТ & GTITAGAAGAAGAGGAGGG \\
\hline \multirow[t]{2}{*}{ p16 } & Unmethylation & TATTAGAGGGTGGGGTGGATTGT & CAACCCCAAACCACAACCATAA \\
\hline & Methylation & ПТАTAGAGGGTGGGGCGGATCGC & GACCCCGAACCGCGACCGTAA \\
\hline sFRP1 & Unmethylation & GTाTGTAGMITGGAGTAGTGTGTGT & CTCAACCTACAATCAAAAACAACACAAACA \\
\hline sFRP4 & Methylation & GGGTGATGTIATCGTIITGTATCGAC & ССTCСССTAACGTAAACTCGAAACG \\
\hline \multirow[t]{2}{*}{ MGMT } & Unmethylation & חाTGTGTITGATGTITGAGGGTाTGT & ААСТССАСАСТСТТССАААААСАAААСА \\
\hline & Methylation & TाTCGACGTTCGTAGGTITCGC & GCACTCTTCCGAAAACGAAACG \\
\hline \multirow[t]{3}{*}{ Sox17 } & Unmethylation & CAAACCAAAAACAAATCCCATATCCAACA & GATाTGTGTGTAGTGMTGTGTTG \\
\hline & Methylation & CAAAAACCAATCCCGTATCCCACG & ПTGCGПAGTCGПTGCGTC \\
\hline & BS-Seq & TAATAAAGTTGATITGGGTATTATAG & СССТАССТАСТАААССТАААААТТС \\
\hline \multirow[t]{2}{*}{ HICl } & Unmethylation & 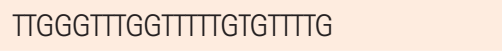 & САСССТААСАССАСССТАAС \\
\hline & Methylation & TCGGTITCGCGMTIGாCGT & AACCGAAAACTATCAACCCTCG \\
\hline \multirow[t]{2}{*}{ p14 } & Unmethylation & ПाাाGGTGTTAAAGGGTGGTGTAGT & CACAAAААСССТСАСТСАСААСАА \\
\hline & Methylation & GTGTTAAAGGGCGGCGTAGC & AAAACCCTCACTCGCGACGA \\
\hline \multirow[t]{2}{*}{ p15 } & Unmethylation & GGTGGTIIIATITGTAGAGTGAGGT & AАССАСТСТАACСАСАAАATACAAACACA \\
\hline & Methylation & GGIIIIATाTGTAGAGCGAGGC & TAACCGCAAAATACGAACGCG \\
\hline \multirow[t]{2}{*}{ GATA5 } & Unmethylation & TGGAGTाGTITIAGGTAGTIITGGT & CAAACCAATACAACTAAACAAACAAACCA \\
\hline & Methylation & AGTCGTITAGGTAGTाTCGGC & CCAATACAACTAAACGAACGAACCG \\
\hline \multirow[t]{2}{*}{ E-cadherin } & Unmethylation & TGGTTGTAGTATGTATTATITIAGTGGTGT & ACACCAAATACAATCAAATCAAACCAAA \\
\hline & Methylation & TGTAGTTACGTATTATIITAGTGGCGTC & CGAATACGATCGAATCGAACCG \\
\hline \multirow[t]{2}{*}{ Timp3 } & Unmethylation & 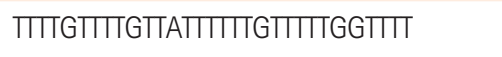 & CССССАААААССССАССТСА \\
\hline & Methylation & CGTTCGTATIITGMTTCGGTTC & CCGAAAACCCCGCCTCG \\
\hline
\end{tabular}

MSP, methylation-specific PCR; BS-Seq, bisulfite sequencing.

purified and subcloned into the pCRII-TOPO vector (Invitrogen, Carlsbad CA, USA). At least 7 clones were randomly selected and sequenced on an ABI3730xl DNA analyzer to as- certain the methylation patterns of each locus. All primers for the bisulfite sequencing analysis are listed in Table 2. 


\section{Statistical Analysis}

All statistical analyses were performed using the STATA 9.2 software package (StataCorp., College Station, TX, USA). The data from most analyses were compared using a $t$-test, while continuous variables were analyzed using the Mann-Whitney $U$-test. $P$-values of less than 0.05 were considered significant.

\section{RESULTS}

\section{Abnormal Hypermethylation of TSGs in CD Patients}

In this study, we investigated transcriptional silencing by promoter hypermethylation of 15 well-known TSG candidates (TFPI2, GATA4, p16, sFRP1, sFRP4, MGMT, Sox17, HIC1, sFRP2, sFRP5, p14, p15, GATA5, E-cadherin, and Timp3) in samples from patients with $\mathrm{CD}$. These genes were previously reported on the basis of comprehensive studies of candidate TSGs in colon cancer, and the transcriptional silencing of these suppressors is regulated by promoter hypermethylation in many cancer types. ${ }^{7}$ In addition, highly sensitive DNA methylation markers in colon cancer could be used to detect the risk level of patients with inflammatory diseases, such as UC and CD.
Motivated by this possibility, we previously analyzed DNA methylation in UC samples ${ }^{15,16}$ and serum samples of CD patients. ${ }^{17}$ Based on previous studies, we were aware of that unknown TSGs could be abnormally hypermethylated in patients with CD. Here, we extracted genomic DNA from patient tissues with CD $(\mathrm{n}=15)$ (Table 1). First, using MSP analysis, we assessed the methylation level of the promoter regions of 15 genes (TFPI2, GATA4, p16, sFRP1, sFRP4, MGMT, Sox17, HIC1, sFRP2, sFRP5, p14, p15, GATA5, E-cadherin, and Timp3) (Table 2) in tissue samples from patient with CD. Conventional MSP analysis was performed successfully with most samples. Fig. 1 displays the frequency of hypermethylation for the 15 gene promoter regions in patient tissues with $\mathrm{CD}$. For most of the CD samples we tested, sFRP1, sFRP2, sFRP5, and Sox17 showed the highest hypermethylation levels (100\% frequencies), and TFPI2, GATA4, sFRP4, GATA5, HIC1, and $p 15$ showed methylation frequencies of $66.7 \%, 60.0 \%, 46.7 \%, 33.3 \%, 13.3 \%$, and $6.7 \%$, respectively. The other 5 genes (p16, p14, E-cadherin, MGMT, and Timp3) showed no methylation in the CD samples.

\section{CD patients}

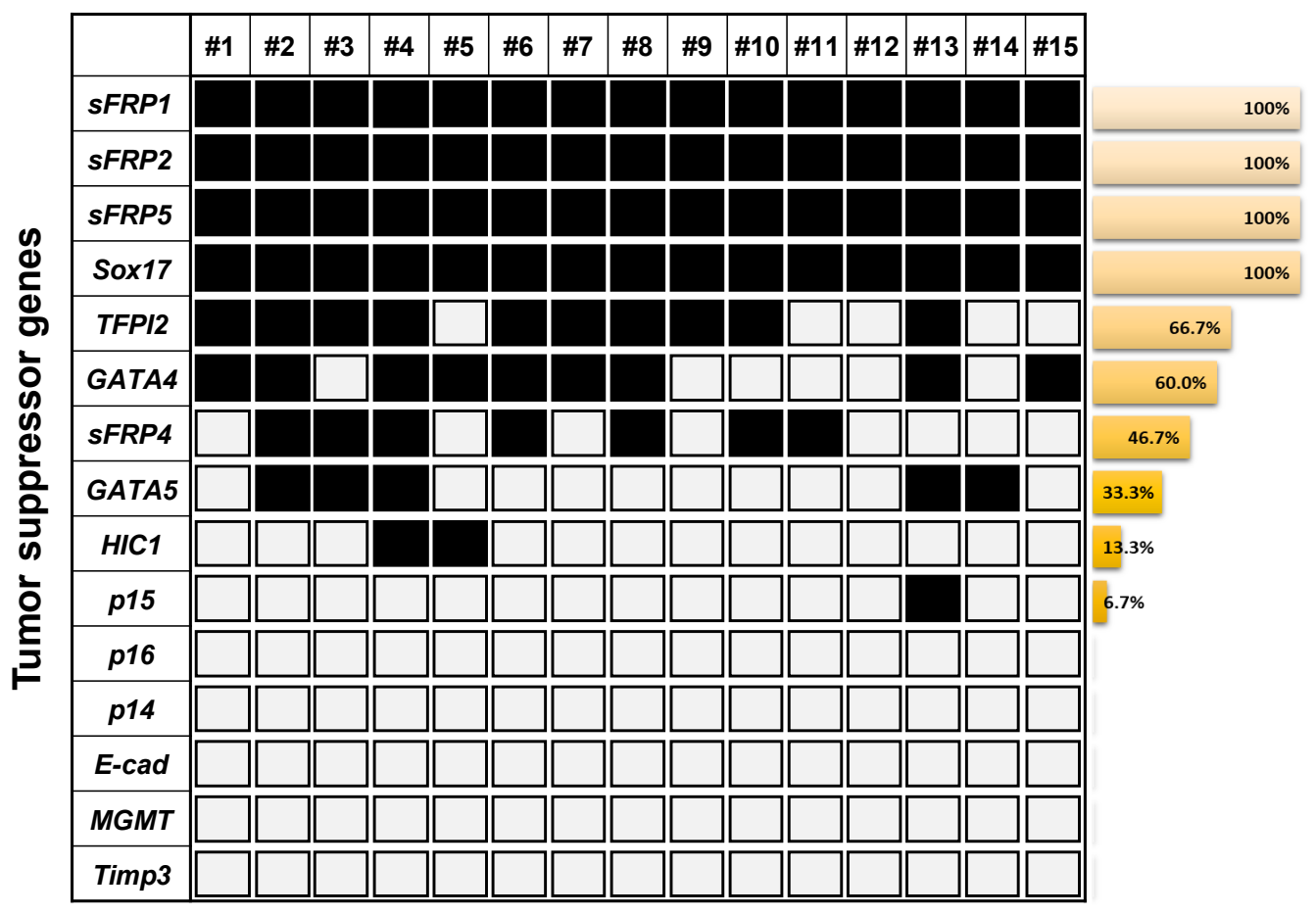

Fig. 1. Summarized results from the methylation analyses on the tumor suppressor genes identified from colon cancer and obtained from patients with $C D$. Each square and number indicates a single $C D$ patient blood sample. The white square indicates the unmethylated $\mathrm{CpG}$ sites. The black square indicates the methylated $\mathrm{CpG}$ sites. The Bar graph presents methylation frequencies of tested genes. E-cad, Ecadherin. 


\section{Six TSGs Are Highly Methylated in CD Patients}

On the basis of the high frequency of methylation of genes (sFRP1, sFRP2, sFRP5, TFPI2, Sox17, and GATA4; >60\% methylation frequencies) in the samples from patients with $\mathrm{CD}$, we next texted the changes in DNA methylation status in the promoter region of the 6 genes by bisulfite genomic sequencing in representative patient tissues with $\mathrm{CD}(\mathrm{n}=3)$. All the genes we tested had previously been shown to be hypermethylated in a cancer-specific manner but are not methylated in normal colon tissues. ${ }^{7}$ The location and extent of the methylated promoter regions used for bisulfite sequencing, relative to the transcription start sites of exon 1, are as follows: $S F R P 1$ : upstream region from -142 to 59, 26 CG sites; $s F R P 2$ : upstream region from -378 to -159, 21 CG sites; sFRP5: upstream region from -296 to -4, 26 CG sites; TFPI2: upstream region from -286 to -76, 30 CG sites; Sox17: region from 339 to 603, 34 CG sites; and GATA4: upstream region from -229 to -161, 46 CG sites. The bisulfite sequencing of the individual clones of 5 PCR products from 3 different individual CD tissue samples revealed densely methylated CG sites within the promoter regions of all the clones (Figs 2,3). The methylation status in the promoter regions of $s F R P 1, T F P I 2$, and $s F R P 2$ in the $\mathrm{CD}$ tissues showed $82.5 \%, 70 \%$, and $63.4 \%$ methylation at the CG sites, respectively. The CG sites of the Sox17, sFRP4, and GATA4 genes in the $\mathrm{CD}$ tissues were methylated in a range from $55 \%$ to $57 \%$. Accordingly, the bisulfite sequencing data confirmed the complete methylation of the 6 gene promoters in patients with $\mathrm{CD}$ as had been determined by the MSP analysis (Fig. 1); that is, 6

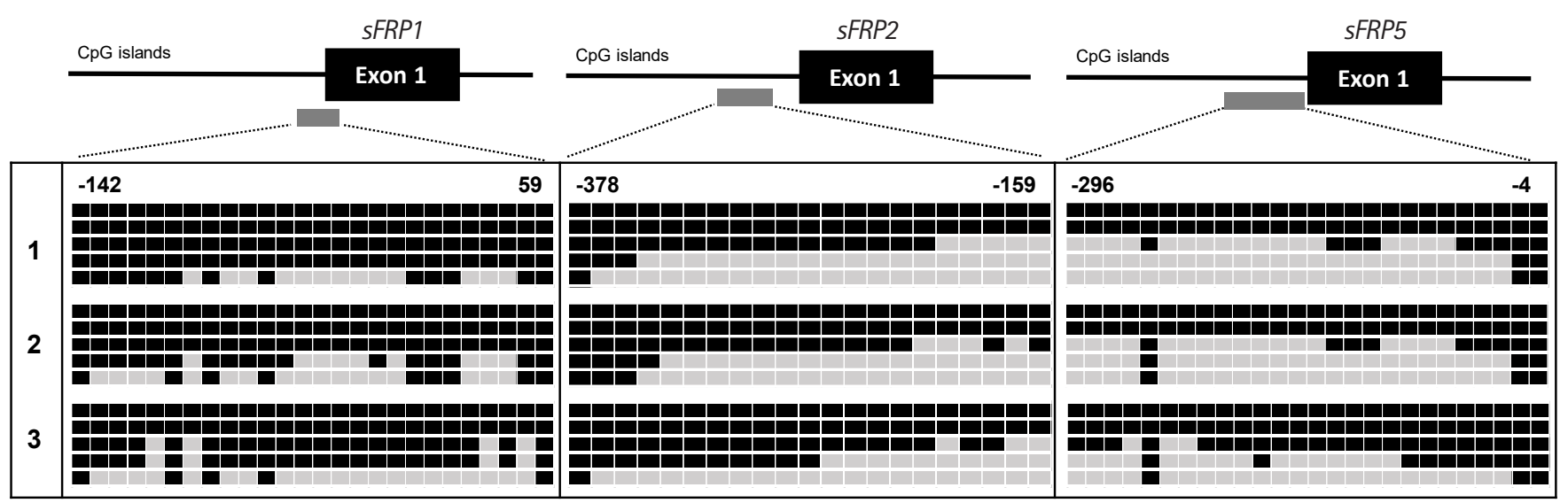

Fig. 2. The methylation level of the promoter region of the $s F R P 1, s F R P 2$, and sFRP5 genes in CD patient samples (patient \#1, \#2, and \#3) as determined by bisulfite sequencing analysis. The location of each $\mathrm{CpG}$ site related to the transcription start site is shown at the bottom of the panels. Open and filled squares indicate methylation and no methylation, respectively.



Fig. 3. The methylation levels of the promoter regions of the GATA4, Sox17, and TFPI2 genes in CD patient samples (patient \#1, \#2, and \#3) as determined by bisulfite sequencing analysis. The location of each $\mathrm{CpG}$ site related to the transcription start site is shown at the bottom of the panels. Open and filled squares indicate methylation and no methylation, respectively. 
genes were significantly hypermethylated in patient samples with CD. Overall, these results strongly suggest that we found increased DNA methylation levels of the $s F R P 1$, sFRP2, sFRP5, TFPI2, Sox17, and GATA4 genes in inflammatory diseases, as represented by $\mathrm{CD}$.

\section{DISCUSSION}

IBD is identified by chronic uncontrolled inflammation of the intestinal mucosa due to abnormal immune response, leading the disruption of the intestinal epithelium. ${ }^{18}$ Patients with IBD can be grouped as lifetime risk (2- to 3-fold greater) of developing CRC, and the most important risk factors for colitis-associated cancer are duration, severity and extent of the IBD. ${ }^{13,14}$ There is a growing body of evidence suggesting that inflammation is the critical cause of many cancers, and colitis-associated cancer serves as a great model system to study the general principles understanding for the etiology of inflammation-associated cancer. ${ }^{19}$ Prevalent evidence supports the theory that IBD is caused by a complex interplay between the predispositions of multiple genes and abnormal interactions with environmental factors. It is becoming increasingly apparent that epigenetic factors can significantly contribute to the pathogenesis of disease.

We have previously reported that the TCERGIL, sFRPI, $F B N 2$, and TFPI2 genes were hypermethylated at high frequency in patients with UC, which is another type of IBD. ${ }^{16} \mathrm{In}$ the present study, we expanded a gene panel consisting mostly of tumor suppressor candidates identified from the colon cancer and tested the methylation level of these genes in patients with CD. According to our previous data and present study, these TSGs are transcriptionally regulated by promoter hypermethylation in patients with IBD. We do not have direct evidences the biological role of these TSGs during IBD development but our data suggest that epigenetically regulated TSGs could contribute to the pathogenesis of IBD. Although lack of studies have been reported that the methylation of TSGs in CD, here we found the promoter methylation changes of SFRP families, TFPI2, Sox17, and GATA4 genes in patients with CD.

The tissue factor pathway inhibitor 2 (TFPI2) gene is located on chromosome 7q22 and encodes a Kunitz-type serine proteinase inhibitor. ${ }^{20}$ TFPI2 can play as a critical roles involved in protecting the extracellular matrix of cancer cells from degradation as well as regulating tumor invasion. ${ }^{21}$ Abnormal promoter hypermethylation of TFPI 2 has been observed in CRC, ${ }^{22}$ gastric cancer, ${ }^{23}$ hepatocellular carcinoma, ${ }^{24}$ pancreatic can$\operatorname{cer}^{25}$ and cervical cancer. ${ }^{26}$ Moreover, promoter hypermethylation of TFPI2 has been detected in recurrence and early-stage $\mathrm{CRC}^{27}$ and in sera from CRC patients with large, poorly differentiated carcinomas, invasion, and several metastasis such as lymph node or distant. ${ }^{28}$ Overall, our study provides the evidences that promoter hypermethylation of TFPI2 is also detected in most of the CD patient samples we tested. This data suggests that TFPI2 may be a useful biomarker during colonoscopic surveillance screening. Therefore, further studies using a large series of samples are necessary to confirm the hypothesis on the TFPI2 gene could be a promising methylation biomarker for screening patients with CD.

Sox 17 encodes an HMG box transcription factor and its biological roles in many different stage of developmental process such as in vascular development and hematopoiesis. ${ }^{29-32}$ The Sox 17 promoter is hypermethylated in cholangiocarcinoma tissues, lung cancer, ${ }^{33}$ gastric cancer, ${ }^{34}$ liver cancer, ${ }^{35}$ and breast cancer. ${ }^{36}$ In addition, inactivated Sox 17 by promoter hypermethylation could contribute to the dysregulaion of the Wnt signaling pathway in human cancer. ${ }^{37}$ These accumulating data strongly suggests that epigenetically silenced Sox 17 can affect to the aberrant activation of Wnt signaling during tumorigenesis in multiple cancer types. ${ }^{38}$ We first report here that Sox 17 is hypermethylated in patients with CD, suggesting that epigenetically inactivated Sox 17 may contribute to the pathogenesis of IBD.

The transcription factor GATA4 plays an essential role in the development and differentiation of the GI tract and is suggested to be involved in CRC development. ${ }^{39,40}$ The lack of GATA4 expression regulated by promoter hypermethylation has been reported in primary CRC, gastric, esophageal, lung, and ovarian cancers. ${ }^{40-43}$ Although accumulating studies on the GATA4 gene is epigenetically regulated in many cancer types, there is lack of information whether GATA4 gene is hypermethylated in patients with $\mathrm{CD}$.

SFRPs belong to the family of Wnt pathway antagonists, and the transcriptional expression of SFRPS are regulated by gene promoter hypermethylation in colon, gastric, ovarian, and lung cancers. ${ }^{44-47}$ Epigenetic regulation of the Wnt pathway was first characterized in colon cancer, which is known to be related to chronic inflammation. Recently, it was shown that the downregulation of SFRP gene family members in gastric and CRC is commonly regulated by promoter hypermethylation. ${ }^{45,48}$ Thus, transcriptional silencing of SFRP gene may affect to leading a mechanism of aberrant Wnt signaling activa- 
tion. ${ }^{45,48}$ It has been reported that the frequent inactivation of SFRP1 and SFRP2 in IBD-associated neoplasia further highlights the importance of the canonical Wnt pathway to understand the pathogenesis of IBD-associated cancer. Our study has some limiting issues. We lacked control samples for CD, such that we could not determine the TSG methylation with specificity in CD patient samples. We also lacked clinical information on the CD samples, such as the disease duration or severity that; therefore, we could not implicate the clinical importance of the promoter methylation of TSGs for the CD patients. Therefore, further study is necessary to define the DNA methylation markers in a large series of clinical data from CD patients, including control samples.

In summary, we investigated the promoter DNA methylation pattern of 15 TSGs in samples from patients with CD. We found that samples from 10 of the 15 patients had TSG promoters that were methylated as determined by conventional MSP analysis. Six TSGs (sFRP1, sFRP2, sFRP5, TFPI2, Sox17, and GATA4) showed a high frequency of hypermethylation in the CD patients, a finding that we confirmed by conducting bisulfite sequencing analysis to determine the methylation levels of the genes in the CD patient tissues. To our knowledge, our study demonstrates for the first time that both the Soxl7 and GATA4 genes are epigenetically regulated in CD patients and the methylation levels of these genes in samples from CD patients. Although we found that promoter of TSGs is frequently hypermethylated in CD patients, we could not implicate the clinical relevance between promoter methylation of TSGs and CD progression.

\section{FINANCIAL SUPPORT}

This study was supported by the 2017 Inje University Research Grant.

\section{CONFLICT OF INTEREST}

No potential conflict of interest relevant to this article was reported.

\section{AUTHOR CONTRIBUTION}

Conceptualization: Kim TO, Yi JM. Methodology: Han YK, Yi JM. Formal analysis: Han YK. Funding acquisition: Kim TO. Project administration: Yi JM. Visualization: Han YK, Yi JM. Writing - original draft: Yi JM. Writing - review and editing: Kim
TO, Yi JM. Approval of final manuscript: all authors.

\section{ORCID}

Kim TO https://orcid.org/0000-0002-7359-1599

Han YK https://orcid.org/0000-0002-3136-4152

Yi JM

\section{AKNOWLEDGEMENTS}

We would like to thank Prof. Khadijah A. Mitchell of the Lafayette College for critically reading the manuscript and providing language editing.

\section{REFERENCES}

1. Podolsky DK. Inflammatory bowel disease. N Engl J Med 2002; 347:417-429.

2. Rivas MA, Beaudoin M, Gardet A, et al. Deep resequencing of GWAS loci identifies independent rare variants associated with inflammatory bowel disease. Nat Genet 2011;43:10661073.

3. Franke A, McGovern DP, Barrett JC, et al. Genome-wide metaanalysis increases to 71 the number of confirmed Crohn's disease susceptibility loci. Nat Genet 2010;42:1118-1125.

4. Liu JZ, van Sommeren S, Huang H, et al. Association analyses identify 38 susceptibility loci for inflammatory bowel disease and highlight shared genetic risk across populations. Nat Genet 2015;47:979-986.

5. Jones PA, Baylin SB. The epigenomics of cancer. Cell 2007;128: 683-692.

6. Schuebel KE, Chen W, Cope L, et al. Comparing the DNA hypermethylome with gene mutations in human colorectal cancer. PLoS Genet 2007;3:1709-1723.

7. Esteller M. Epigenetic gene silencing in cancer: the DNA hypermethylome. Hum Mol Genet 2007;16 Spec No 1:R50-R59.

8. Shen L, Kondo Y, Guo Y, et al. Genome-wide profiling of DNA methylation reveals a class of normally methylated $\mathrm{CpG}$ island promoters. PLoS Genet 2007;3:2023-2036.

9. Robertson KD. DNA methylation and human disease. Nat Rev Genet 2005;6:597-610.

10. Maeda O, Ando T, Watanabe O, et al. DNA hypermethylation in colorectal neoplasms and inflammatory bowel disease: a mini review. Inflammopharmacology 2006;14:204-206.

11. Tahara T, Shibata T, Nakamura M, et al. Effect of MDR1 gene promoter methylation in patients with ulcerative colitis. Int J 
Mol Med 2009;23:521-527.

12. Heyn H, Esteller M. DNA methylation profiling in the clinic: applications and challenges. Nat Rev Genet 2012;13:679-692.

13. Kang K, Bae JH, Han K, Kim ES, Kim TO, Yi JM. A genomewide methylation approach identifies a new hypermethylated gene panel in ulcerative colitis. Int J Mol Sci 2016;17:E1291.

14. Kim TO, Park J, Kang MJ, et al. DNA hypermethylation of a selective gene panel as a risk marker for colon cancer in patients with ulcerative colitis. Int J Mol Med 2013;31:1255-1261.

15. Bae JH, Park J, Yang KM, Kim TO, Yi JM; IBD Study Group of Korean Association for Study of Intestinal Diseases (KASID). Detection of DNA hypermethylation in sera of patients with Crohn's disease. Mol Med Rep 2014;9:725-729.

16. Hanauer SB. Inflammatory bowel disease: epidemiology, pathogenesis, and therapeutic opportunities. Inflamm Bowel Dis 2006;12 Suppl 1:S3-S9.

17. Bernstein CN, Blanchard JF, Kliewer E, Wajda A. Cancer risk in patients with inflammatory bowel disease: a populationbased study. Cancer 2001;91:854-862.

18. Bernstein CN, Blanchard JF, Rawsthorne P, Wajda A. Epidemiology of Crohn's disease and ulcerative colitis in a central Canadian province: a population-based study. Am J Epidemiol 1999;149:916-924.

19. Colotta F, Allavena P, Sica A, Garlanda C, Mantovani A. Cancer-related inflammation, the seventh hallmark of cancer: links to genetic instability. Carcinogenesis 2009;30:1073-1081.

20. Rollin J, Iochmann S, Bléchet C, et al. Expression and methylation status of tissue factor pathway inhibitor-2 gene in nonsmall-cell lung cancer. Br J Cancer 2005;92:775-783.

21. Gerecke C, Scholtka B, Löwenstein Y, et al. Hypermethylation of ITGA4, TFPI2 and VIMENTIN promoters is increased in inflamed colon tissue: putative risk markers for colitis-associated cancer. J Cancer Res Clin Oncol 2015;141:2097-2107.

22. Glöckner SC, Dhir M, Yi JM, et al. Methylation of TFPI2 in stool DNA: a potential novel biomarker for the detection of colorectal cancer. Cancer Res 2009;69:4691-4699.

23. Hibi K, Goto T, Kitamura YH, et al. Methylation of the TFPI2 gene is frequently detected in advanced gastric carcinoma. Anticancer Res 2010;30:4131-4133.

24. Sun FK, Fan YC, Zhao J, et al. Detection of TFPI2 methylation in the serum of hepatocellular carcinoma patients. Dig Dis Sci 2013;58:1010-1015.

25. Kisiel JB, Yab TC, Taylor WR, et al. Stool DNA testing for the detection of pancreatic cancer: assessment of methylation marker candidates. Cancer 2012;118:2623-2631.

26. Dong Y, Tan Q, Tao L, et al. Hypermethylation of TFPI2 corre- lates with cervical cancer incidence in the Uygur and Han populations of Xinjiang, China. Int J Clin Exp Pathol 2015;8: 1844-1854.

27. Rasmussen SL, Krarup HB, Sunesen KG, Pedersen IS, Madsen PH, Thorlacius-Ussing O. Hypermethylated DNA as a biomarker for colorectal cancer: a systematic review. Colorectal Dis 2016;18:549-561.

28. Hibi K, Goto T, Shirahata A, et al. Detection of TFPI2 methylation in the serum of colorectal cancer patients. Cancer Lett 2011;311:96-100.

29. Sohn J, Natale J, Chew LJ, et al. Identification of Sox17 as a transcription factor that regulates oligodendrocyte development. J Neurosci 2006;26:9722-9735.

30. Matsui T, Kanai-Azuma M, Hara K, et al. Redundant roles of Sox17 and Sox18 in postnatal angiogenesis in mice. J Cell Sci 2006;119(Pt 17):3513-3526.

31. Park KS, Wells JM, Zorn AM, Wert SE, Whitsett JA. Sox17 influences the differentiation of respiratory epithelial cells. Dev Biol 2006;294:192-202.

32. Kim I, Saunders TL, Morrison SJ. Sox17 dependence distinguishes the transcriptional regulation of fetal from adult hematopoietic stem cells. Cell 2007;130:470-483.

33. Hulbert A, Jusue-Torres I, Stark A, et al. Early detection of lung cancer using DNA promoter hypermethylation in plasma and sputum. Clin Cancer Res 2017;23:1998-2005.

34. Oishi Y, Watanabe Y, Yoshida Y, et al. Hypermethylation of Sox17 gene is useful as a molecular diagnostic application in early gastric cancer. Tumour Biol 2012;33:383-393.

35. Jia Y, Yang Y, Liu S, Herman JG, Lu F, Guo M. SOX17 antagonizes WNT/beta-catenin signaling pathway in hepatocellular carcinoma. Epigenetics 2010;5:743-749.

36. Fu DY, Wang ZM, Li-Chen, et al. Sox17, the canonical Wnt antagonist, is epigenetically inactivated by promoter methylation in human breast cancer. Breast Cancer Res Treat 2010;119: 601-612.

37. Zhang W, Glöckner SC, Guo M, et al. Epigenetic inactivation of the canonical Wnt antagonist SRY-box containing gene 17 in colorectal cancer. Cancer Res 2008;68:2764-2772.

38. Clevers H. Wnt/beta-catenin signaling in development and disease. Cell 2006;127:469-480.

39. Gao X, Sedgwick T, Shi YB, Evans T. Distinct functions are implicated for the GATA-4, -5 , and -6 transcription factors in the regulation of intestine epithelial cell differentiation. Mol Cell Biol 1998;18:2901-2911.

40. Akiyama Y, Watkins N, Suzuki H, et al. GATA-4 and GATA-5 transcription factor genes and potential downstream antitu- 
mor target genes are epigenetically silenced in colorectal and gastric cancer. Mol Cell Biol 2003;23:8429-8439.

41. Guo M, Akiyama Y, House MG, et al. Hypermethylation of the GATA genes in lung cancer. Clin Cancer Res 2004;10:79177924.

42. Guo M, House MG, Akiyama Y, et al. Hypermethylation of the GATA gene family in esophageal cancer. Int J Cancer 2006;119: 2078-2083.

43. Wakana K, Akiyama Y, Aso T, Yuasa Y. Involvement of GATA4/-5 transcription factors in ovarian carcinogenesis. Cancer Lett 2006;241:281-288.

44. Suzuki H, Watkins DN, Jair KW, et al. Epigenetic inactivation of SFRP genes allows constitutive WNT signaling in colorectal cancer. Nat Genet 2004;36:417-422.

45. Cheng YY, Yu J, Wong YP, et al. Frequent epigenetic inactiva- tion of secreted frizzled-related protein 2 (SFRP2) by promoter methylation in human gastric cancer. Br J Cancer 2007;97: 895-901.

46. Su HY, Lai HC, Lin YW, et al. Epigenetic silencing of SFRP5 is related to malignant phenotype and chemoresistance of ovarian cancer through Wnt signaling pathway. Int J Cancer 2010; 127:555-567.

47. Fukui T, Kondo M, Ito G, et al. Transcriptional silencing of secreted frizzled related protein 1 (SFRP 1) by promoter hypermethylation in non-small-cell lung cancer. Oncogene 2005; 24:6323-6327.

48. Nojima M, Suzuki H, Toyota M, et al. Frequent epigenetic inactivation of SFRP genes and constitutive activation of Wnt signaling in gastric cancer. Oncogene 2007;26:4699-4713. 